\title{
THE IMPACT OF PERCEIVED \\ COUNTERFEIT LUXURY BRAND \\ PROLIFERATION ON LUXURY BRAND \\ VALUES AND PATRONAGE INTENTION
}

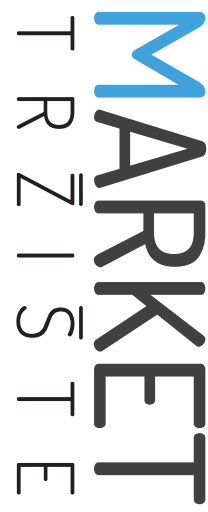

\section{UTJECAJ PERCIPIRANOG ŠIRENJA KRIVOTVORINA LUKSUZNIH MARAKA NA NJIHOVU VRIJEDNOST I MOGUĆE POKROVITELJSTVO}

\author{
Market-Tržište \\ Vol. 30, No. 1, 2018, pp. 41-60 \\ UDK 366.12:658.626(5-12) \\ DOI http://dx.doi.org/10.22598/mt/2018.30.1.41 \\ Original scientific paper
}

\begin{abstract}
Natee Srisomthavil ${ }^{a}$, Nuttapol Assarut ${ }^{b}$
a) Chulalongkorn University, Chulalongkorn Business School, Phyathai Road, Pathumwan, 10330, Bangkok, THAILAND, natee. sr578@cbs.chula.ac.th

b) Chulalongkorn University, Chulalongkorn Business School, Phyathai Road, Pathumwan, 10330, Bangkok, THAILAND, nuttapol@cbs.chula.ac.th
\end{abstract}

\begin{abstract}
Purpose - The purpose of this research is to explore the impact of perceived counterfeit proliferation (PCP) on five luxury brand values of an original luxury fashion brand. This research also explores the correlations between luxury brand values and patronage intention.

Design/Methodology/Approach - Two hundred and twenty survey questionnaires were collected, and the partial least square structural equation modeling (PLSSEM) technique was used to analyze data.

Findings and implications - The results indicated that PCP has a statistically significant impact on uniqueness value only, while quality, hedonic, conspicuous, and extended-self values are not affected for Southeast Asian consumers. This suggests that a proliferation of counterfeit luxury brands cannot be viewed in the same way as authentic luxury brand proliferation, which tend to have negative impacts on other brand values apart from uniqueness value. On the other hand, the luxury brand values that have significant statistical relationships with patronage intention are quality, hedonic, and extended-self values, suggesting that Southeast Asian consum-
\end{abstract}

\section{Sažetak}

Svrha - Svrha je rada istražiti utjecaje percipiranog širenja krivotvorina na pet vrijednosti originalne luksuzne modne marke. Ovo istraživanje istražuje i odnose između vrijednosti luksuzne marke i namjere pokroviteljstva.

Metodološki pristup - Prikupljeno je dvjesto dvadeset anketnih upitnika, a za analizu podataka korištena je metoda modeliranja strukturnih jednadžbi, parcijalnih najmanjih kvadrata.

Rezultati i implikacije - Rezultati pokazuju da za potrošače iz Jugoistočne Azije percipirano širenje krivotvorina ima statistički značajan utjecaj jedino na vrijednost jedinstvenosti, ali ne i na vrijednosti kvalitete, hedonizma, upadljivosti i proširenja vlastitih vrijednosti. Navedeno upućuje na to da se širenje krivotvorina luksuznih maraka ne može promatrati na jednak način kao i širenje autentičnih luksuznih maraka, koje imaju tendenciju negativnog utjecaja na vrijednosti drugih maraka, osim na vrijednost jedinstvenosti. No vrijednosti luksuzne marke koje imaju značajnu statističku povezanost s namjerom pokroviteljstva jesu kvaliteta, hedonizam i proširenje vlastitih vrijednosti, što sugerira da potrošači iz Jugoi- 
ers mainly base their patronage intention on personal motives rather than on interpersonal motives.

Limitations - The only luxury fashion brand studied in this study is Louis Vuitton, which could limit the generalizability of results. Also, the effect of cultural difference was not explored. It is advisable for future research to explore the moderating effects of culture.

Originality - To the best of our knowledge, this research is one of only a few to quantitatively study the effects of PCP on the five dimensions of luxury brand values.

Keywords - luxury brand values, luxury fashion brands, counterfeit luxury brands, perceived counterfeit proliferation stočne Azije uglavnom svoju namjeru pokroviteljstva radije temelje na osobnim nego na međuosobnim motivima.

Ograničenja - Jedina luksuzna modna marka promatrana u ovom istraživanju jest Louis Vuitton, što može ograničiti generalizaciju dobivenih rezultata. Isto tako nije istražen utjecaj kulturoloških različitosti. Za buduća istraživanja preporučuje se istražiti moderirajuće utjecaje kulture.

Doprinos - Prema našem saznanju, ovo je istraživanje jedno od rijetkih koje na kvantitativan način proučava učinke percipiranog širenja krivotvorina na pet dimenzija vrijednosti luksuzne marke.

Ključne riječi - vrijednosti luksuzne marke, luksuzne modne marke, krivotvorine luksuznih maraka, percipirano širenje krivotvorina 


\section{INTRODUCTION}

Luxury fashion brand counterfeiting is currently a problem at a global level. The estimated total value of counterfeits sold worldwide is as high as 1.8 trillion US dollars (The Economist, 2015). Moreover, according to the Business Action to Stop Counterfeiting and Piracy (BAS(AP), the number of counterfeits has grown over 10,000 percent over the past twenty years (Lowe, 2013).

Amidst the growing problems of counterfeits worldwide, publications on the antecedents to counterfeit consumption are abundant. However, more research is needed to better understand how counterfeit products affect authentic luxury brand users and the authentic brands themselves (Amaral \& Loken, 2016). Thus, this research aims to contribute to the better understanding of how counterfeit proliferation affects luxury brand values and how these values affect patronage intention.

Theoretically, counterfeit products should serve to tarnish the image and brand values of the original luxury brands due to their severe loss in exclusivity and uniqueness (Hieke, 2010; Hilton, Choi \& Chen, 2004). However, some research maintains that counterfeits do not devalue the original luxury fashion brand (Hieke, 2010; Nia \& Zaichkowsky, 2000). Some even assert that counterfeits actually benefit the authentic brands (Gabrielli, Grappi \& Baghi, 2012; Romani, Gistri \& Pace, 2012). On the other hand, Commuri (2009) suggests that counterfeits negatively affect consumers' brand patronage. Amaral and Loken (2016) also show that counterfeits actually have adverse effects on the prestige-attitude towards the original luxury fashion brands. Therefore, evidence on the effects of counterfeits on original luxury brands remains inconclusive.

To the best of our knowledge, very few past studies have comprehensively studied how counterfeit proliferation affects the different dimensions of luxury brand value. According to Vigneron and Johnson (2004), luxury brand value can be divided into quality value, hedonic value, conspicuous value, extended-self value, and uniqueness value. It is highly possible that counterfeits only affect some dimensions of brand value while not affecting others. As brand value affects consumers' preference for the brand (Armstrong \& Kotler, 2013; Tynan, McKechnie \& Chhuon, 2010), it is important to investigate how counterfeit proliferation affects all the brand value dimensions in order to get a complete picture.

In order to address the gaps mentioned above, this study aims to explore how perceived counterfeit proliferation affects the original brand's five luxury brand values and how those five brand values affect consumer patronage intention. In particular, this research aims to answer the following research question: What is the impact of perceived counterfeit proliferation on the five luxury brand values of an original luxury fashion brand and how do those brand values affect consumer patronage intention?

The contribution of this research is twofold. First, it provides a better understanding of how counterfeit proliferation affects the five luxury brand values of the original brand. Second, it contributes to a better understanding of how the five luxury brand values affect luxury brand patronage intention. Therefore, this research helps to comprehensively identify which of the five luxury brand values are affected by counterfeit proliferation and which of these five values are related to patronage intention. The results will help academicians get a more complete picture of the impact of counterfeit proliferation on luxury brand values and patronage intention. Brand managers will also be able to better manage their brands by gaining more insight on which brand values actually influence their sales performance.

It is important to note that this study will focus on the luxury fashion brand, Louis Vuitton, which is one of the most popular luxury fashion brands and among the most counterfeited according to our interviews with respondents.

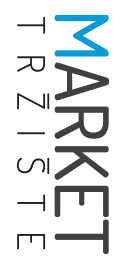




\section{LITERATURE REVIEW}

\subsection{Luxury brand value}

Brand value refers to the total benefit that customers receive from a brand and, once leveraged, allows the brand to achieve superior current and future returns (Keller, 2016; Lassar, Mittal \& Sharma, 1995). Luxury brand value therefore refers to the total benefit that customers will get from consuming luxury brands. Vigneron and Johnson (2004) proposed that there are five dimensions to luxury brand value: quality value $(Q V)$, hedonic value $(H V)$, conspicuous value $(C V)$, extended-self value (EV), and uniqueness value (UV).

Quality value (QV) is the superior quality of luxury products expected by consumers when compared to non-luxury products (Vigneron \& Johnson, 2004). The term "superior quality" in the context of luxury fashion brands refers to exceptional design, durability, reliability, and craftsmanship (Chattalas \& Shukla, 2015; Dubois, Laurent \& Czellar, 2001; Kapferer, 1998). The quality value construct studied in this research is closely related to "functional value", as proposed by Sheth, Newman and Gross (1991) and Sweeney and Soutar (2001).

Studies by Vigneron and Johnson (1999) and Sun, D'Alessandro and Johnson (2016) revealed that superior craftsmanship and creativity are what consumers look for in luxury fashion brands. A study by Dubois and others (2001) also suggested that the relationship between the concept of luxury and quality is so strong that the two words are almost equivalent. As the authors above generally agree that superior quality is what consumers seek from luxury fashion brands, we argue that a luxury fashion brand's QV is directly related to consumers' patronage intention (PI).

H1: The quality value of an authentic luxury fashion brand will have a positive impact on consumers' intention to patronize the brand.

Hedonic value $(H V)$ represents the sensory pleasures and rewards consumers receive through the consumption of luxury brands (Vigneron \& Johnson, 2004). Compared to the work by Sheth and others (1991) and Sweeney and Soutar (2001), this concept is equivalent to emotional value. HV is conceptually inner-directed and does not involve interpersonal influence (Vigneron \& Johnson, 2004). Inner-directed, in this context, means that the satisfaction judgment is based only on the product and the consumer's own self (Kahle, 1995; Vigneron \& Johnson, 2004). Consumers who consume luxury brands mainly on the brands' $\mathrm{HV}$ are usually not influenced by pressure from group norms (Flynn, Goldsmith \& Pollitte, 2016; Kahle, 1995).

A study by Wiedmann, Hennigs and Siebels (2009) revealed that sensory pleasures and self-enjoyment experienced during the use of a luxury brand are among the benefits that consumers sought through luxury brand consumption. Since luxury consumption is highly hedonic (Dubois et al., 2001), we argue that a luxury fashion brand's HV is directly related to consumers' intention to patronize the brand.

H2: The hedonic value of an authentic luxury fashion brand will have a positive impact on consumers' intention to patronize the brand.

Conspicuous value $(\mathrm{CV})$ is the value that allows users to convey status and membership of an aspirational group through the use of a luxury brand (Vigneron \& Johnson, 2004; Wiedmann et al., 2009). Therefore, CV is mainly derived from how consumers are able to improve the way they are perceived and feel socially accepted by other people. Compared to the work by Sheth and others (1991) and Sweeney and Soutar (2001), CV is equivalent to the concept of social value.

According to the Theory of the Leisure Class (Veblen, 1989), people generally try to distance themselves from those of a lower social class while aspiring to be accepted by members of the higher class. Goldsmith, Flynn and Kim (2010) and Flynn and others (2016) suggested that people use luxury brands to prevent social 
rejection and to claim a desirable vertical location in the social hierarchy. As climbing up the social ladder is generally desirable (Corneo \& Jeanne, 1997; Kasser, 2016), we argue that the CV of a luxury brand positively affects consumers' intention to patronize the brand.

H3: The conspicuous value of an authentic luxury fashion brand will have a positive impact on consumers' intention to patronize the brand.

Extended-self value (EV) is the value derived from the consumers' ability to portray their self-concept through the use of a luxury brand (Vigneron \& Johnson, 2004). Apart from functional purposes, consumers also use luxury brands to portray their desired self-image (Belk, 1988; Dittmar, 1994).

Sirgy (1985) and Sirgy, Grewal and Mangleburg (2000) suggested that consumers generally adopt brands that have images congruent to the self-identity that they wish to convey; hence, they are less likely to adopt brands that do not convey the desired image. Following this line of logic, we can conclude that consumers generally seek to incorporate the desired symbolic meanings of luxury brands into their own self-identity (Holt, 1995; Vigneron \& Johnson, 2004; Wiedmann et al., 2009). Therefore, we argue that the EV of a luxury brand positively affects consumers' intention to patronize the brand.

H4: The extended-self value of an authentic luxury fashion brand will have a positive impact on consumers' intention to patronize the brand.

Uniqueness value (UV) is the value derived from possessing scarce goods that others cannot access (Vigneron \& Johnson, 1999; Vigneron \& Johnson, 2004). UV studied in this research is conceptually distinct from EV. This is because $U V$ is derived from the possession of goods that are unobtainable by others, while EV is derived from consumers' ability to portray an exclusive image through the use of a luxury brand.

Lynn (1991) reported that the more the supply of a product is perceived to be limited, the more consumers' preference for the brand is enhanced. Dubois and others (2001) and Chen and Lamberti (2015) also reported that scarcity and uniqueness form one of the facets of luxury brands. Luxury products in the minds of consumers are those that require uncommon skills to manufacture and, thus, cannot be mass-produced. According to the Commodity Theory, "any commodity will be valued to the extent that it is unavailable" (Brock, 1968, p. 246 as cited in Lynn, 1991). Therefore, we argue that the UV of a luxury brand positively affects consumers' intention to patronize the brand.

H5: The uniqueness value of an authentic luxury fashion brand will have a positive impact on consumers' intention to patronize the brand.

The patronage intention (PI) construct will be used to conceptualize consumers' intention to patronize the brand. This construct is used in place of purchase intention to reflect the fact that the construct not only measures the respondents' intention to purchase the product but also their intention to refer the product to others. Even though past studies, such as those ones by Moon, Chadee and Tikoo (2008) and Hieke (2010), have included an item on the intention to recommend the products to others as a measurement item for purchase intention, we feel that the term "patronage" would better reflect the phenomenon for luxury brands. Therefore, the patronage intention (PI) construct will be used in this research.

\subsection{Perceived counterfeit luxury brand proliferation}

Past studies, such as those by Fournier (1998), Hellofs and Jacobson (1999) and Commuri (2009) have suggested that fake products contribute to the loss of exclusivity of the original brand. Lee (2011) also reported that consumers believe that counterfeit products damage the original luxury brand's image because they cause the original products to be less rare.

Despite evidence on how counterfeit luxury products may damage the uniqueness of the original brand, very few studies have tried to quantitatively explore the manner in which the

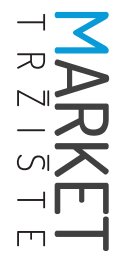


perceived proliferation of counterfeit products affects the values of original luxury brands. Also, no measurement scales have been developed to measure perceived counterfeit proliferation. Therefore, measurement scales for perceived counterfeit proliferation (PCP) will be developed in this research. We would define the PCP construct as the consumers' perception of how much counterfeit luxury fashion brand products are being proliferated, as reflected by how much they are, or will be, available on the market and how much they are being adopted by other consumers.

As the proliferation of counterfeits causes consumers to feel that the original brand is less rare (Commuri, 2009; Fournier, 1998; Hellofs \& Jacobson, 1999; Lee, 2011), it is logical to conclude, based on the Commodity Theory (Brock, 1968 as cited in Lynn, 1991), that the perceived proliferation of counterfeit products negatively affects the UV of the original luxury brand.

H6: Perceived counterfeit proliferation will have a negative impact on the uniqueness value of the original luxury fashion brand.

PCP can also have an impact on a luxury brand's EV. Counterfeit luxury brand users are generally viewed as being less affluent or located at the lower levels of the social hierarchy (Chuchinprakarn, 2003; Commuri, 2009; Gentry, Putrevu $\&$ Shultz, 2006). When counterfeit luxury products are widely adopted, the negative images of counterfeit users can spillover onto the users of the genuine brand (Amaral \& Loken, 2016). This serves to dilute the image of luxury fashion brands and, hence, the ability for consumers to construct their desired self-image through the use of the brands. We therefore argue that PCP will correlate negatively with the original luxury fashion brand's EV.

H7: Perceived counterfeit proliferation will have a negative impact on the extended-self value of the original luxury fashion brand.

Similar to EV, PCP can also affect a luxury brand's $C V$. When counterfeits are proliferated throughout the market, it is possible that they will be adopted by nonmembers of the aspirational groups. Simmel (1957) mentioned that adoption of a fashion by the mass can obliterate the status signaling vibe of the fashion. Yang and Mattila (2014) also found that status-seeking consumers exhibit a negative attitudinal change towards luxury brands when they become aware that those brands are being adopted by less affluent masses. As counterfeit luxury products carry the trademark of the original brands (Wang \& Song, 2013), counterfeit proliferation can affect the original brand through the trademark link (Amaral \& Loken, 2016). We therefore argue that $C V$ is negatively affected by PCP.

H8: Perceived counterfeit proliferation will have a negative impact on the conspicuous value of the original luxury fashion brand.

$H V$, on the other hand, should not be affected by counterfeit proliferation. $H V$, as discussed above, is conceptually inner-directed and does not involve interpersonal influence (Vigneron \& Johnson, 2004). PCP, on the other hand, involves interpersonal comparison. That is, it involves the perception of how much counterfeit products of a luxury brand are being used by other people. Therefore, we argue that PCP is not related to the HV of the original brand.

H9: Perceived counterfeit proliferation will have no significant impact on the hedonic value of the original luxury fashion brand.

Lastly, PCP is a construct that involves consumers' perception of how much counterfeit products are being widely available or adopted by the general public. This is conceptually not related to the quality of the original brand. We therefore argue that PCP is not related to the QV of the original brand.

H10: Perceived counterfeit proliferation will have no significant impact on the quality value of the original luxury fashion brand.

Figure 1 outlines the research framework and all the hypotheses developed above. 


\section{FIGURE 1: Research Framework}

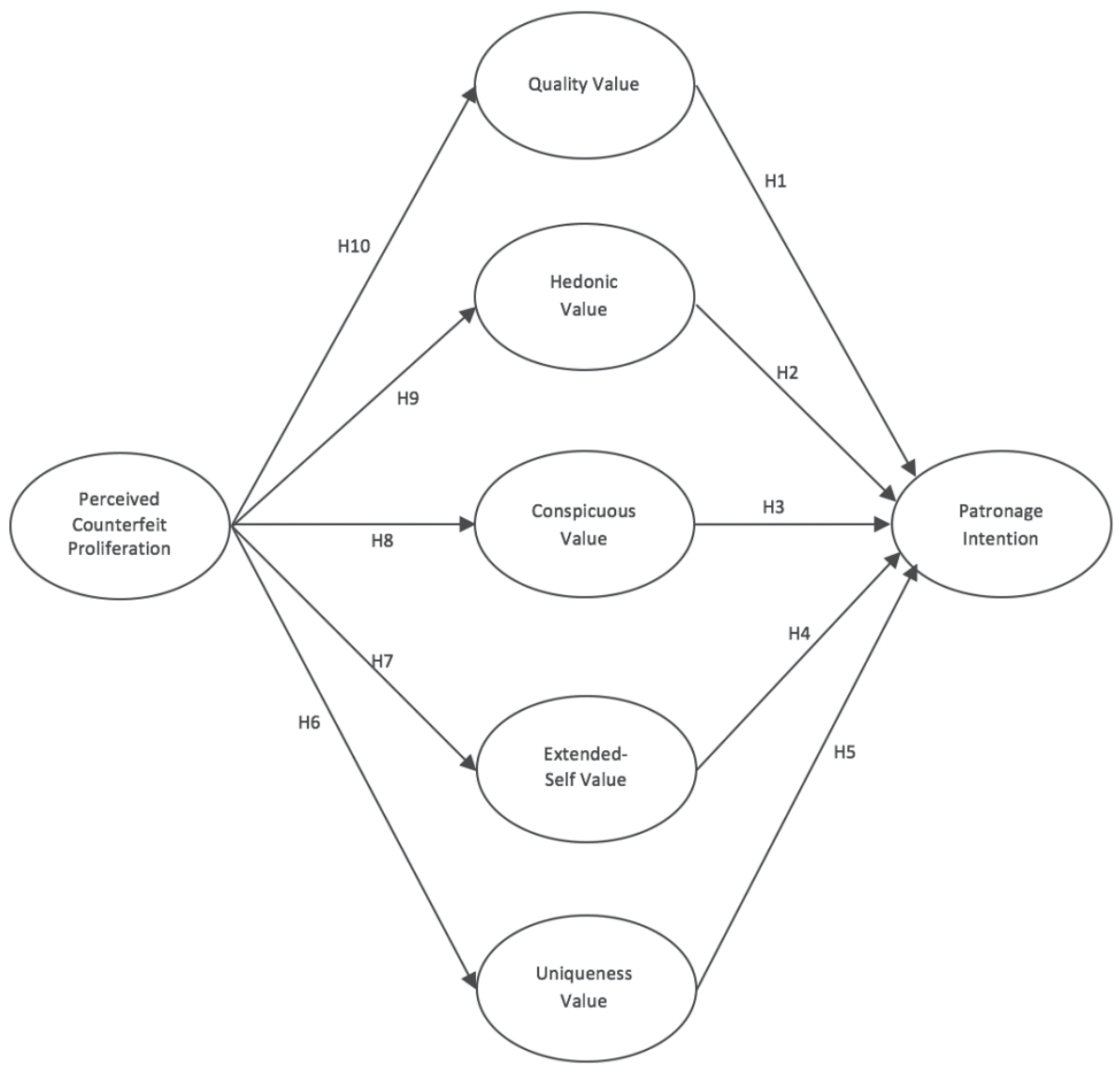

\section{METHODOLOGY}

\subsection{Sample}

Samples were collected from male and female consumers living in Bangkok, Thailand. Thailand was selected because it has the largest luxury goods market in Southeast Asia (Deloitte, 2015), and Bangkok would be the best city to collect the data because the customers of luxury products are concentrated there (Euromonitor, 2016). Thailand has also long been experiencing problems with counterfeit trafficking (Commuri, 2009), and counterfeit luxury brand products are available in multiple markets in Bangkok (Ehrlich, 2015). Therefore, Thailand would very much be a suitable location to conduct our study.
As Louis Vuitton (LV) was studied in this research, consumers who do not know LV were excluded from the study. Also, since the possession of counterfeited LV products can affect respondents' opinion towards the brand values of $L V$, the respondents who reported owning counterfeited LV were excluded from the study. This was done to prevent any possible confounding factors that might affect the luxury brand value apart from PCP. In the end, a total of 220 surveys were used for the analyses. The demographic information of the respondents is summarized in Table 1. 


\section{TABLE 1: Respondents' demographic information}

\begin{tabular}{|l|l|r|r|}
\hline & & Count & Percentage \\
\hline Gender & Male & 95 & $43 \%$ \\
& Female & 125 & $57 \%$ \\
\hline Age & 22 to 25 years old & 22 & $10 \%$ \\
& 26 to 35 years old & 192 & $87 \%$ \\
& 36 to 53 years old & 6 & $3 \%$ \\
\hline Education & Less than bachelor's degree & 1 & $0.5 \%$ \\
& Bachelor's degree & 27 & $12.5 \%$ \\
& Higher than bachelor's degree & 192 & $87 \%$ \\
\hline Income & Less than 30,000 baht & 22 & $10 \%$ \\
& $30,000-59,999$ baht & 117 & $53 \%$ \\
& $60,000-89,999$ baht & 17 & $21 \%$ \\
& $90,000-119,999$ baht & 12 & $8 \%$ \\
& 120,000 baht or above & 5 & $5 \%$ \\
\hline Total sample size & Not reported & 220 & $100 \%$ \\
\hline
\end{tabular}

\subsection{Measures}

\subsubsection{Measurement item adaptations}

Measurement items for the constructs QV, HV, and $\mathrm{CV}$ were adapted from those developed by Sweeney and Soutar (2001) by simply adding the name of the luxury fashion brand into the items. Similarly, the measurement items for EV and UV were adapted from the ones developed by Wiedmann and others (2009). The scales were developed by Wiedmann and others (2009) for segmenting luxury brand consumers and not specifically for measuring luxury brand values. Therefore, the measurement items were adapted by modifying the wording of the items from originally measuring the respondents' general opinions regarding the antecedents to luxury brand consumption to measuring opinions specific to a luxury fashion brand. The measurement items for $\mathrm{Pl}$ are a combination of the items used by Hieke (2010) and Yoo and Lee (2009). All the adapted measurement items are listed in Table 2. 
TABLE 2: Measurement items adapted for this research

\begin{tabular}{|c|c|c|}
\hline $\begin{array}{l}\text { Item } \\
\text { Labels }\end{array}$ & Measurement Items & Author(s) \\
\hline & Quality Value & \\
\hline \multirow[t]{2}{*}{$\begin{array}{l}\text { QV_1 } \\
\text { QV_2 } \\
\text { QV_3 } \\
\text { QV_4 } \\
\text { QV_5 } \\
\text { QV_6 }\end{array}$} & $\begin{array}{l}{[\text { Brand } X] \text { has an acceptable standard of quality }} \\
{[\text { Brand } X] \text { is well made }} \\
{[\text { Brand } X] \text { has poor workmanship }(R)} \\
{[\text { Brand } X] \text { would not last a long time }(R)} \\
{[\text { Brand } X] \text { would perform consistently }} \\
{[\text { Brand } X] \text { has superior quality than other fashion products in general }}\end{array}$ & $\begin{array}{l}\text { Sweeney \& } \\
\text { Soutar (2001) }\end{array}$ \\
\hline & Hedonic Value & \\
\hline \multirow[t]{2}{*}{$\begin{array}{l}\mathrm{HV} \_1 \\
\mathrm{HV} \_2 \\
\mathrm{HV} \_3 \\
\mathrm{HV} \_4 \\
\mathrm{HV} \_5\end{array}$} & $\begin{array}{l}{[\text { Brand } X] \text { is the one that I would enjoy }} \\
{[\text { Brand } X] \text { would make me want to use it }} \\
{[\text { Brand } X] \text { is the one that I would feel relax about using }} \\
{[\text { Brand } X] \text { would make me feel good }} \\
{[\text { Brand } X] \text { would not give me pleasure }(R)}\end{array}$ & $\begin{array}{l}\text { Sweeney \& } \\
\text { Soutar (2001) }\end{array}$ \\
\hline & Conspicuous Value & \\
\hline \multirow[t]{2}{*}{$\begin{array}{l}C V_{-} 1 \\
C V_{-2} \\
C V_{-3} \\
C V_{-4}\end{array}$} & $\begin{array}{l}\text { [Brand X] would make a good impression on other people } \\
{[\text { Brand X] would improve the way I am perceived }} \\
{[\text { Brand X] would give its owner social approval }} \\
{[\text { Brand X] would not help me to feel acceptable (R) }}\end{array}$ & $\begin{array}{l}\text { Sweeney \& } \\
\text { Soutar (2001) }\end{array}$ \\
\hline & Extended-Self Value & \\
\hline \multirow[t]{2}{*}{$\begin{array}{l}E V_{-} 1 \\
E V_{-} 2 \\
E V_{-} 3\end{array}$} & $\begin{array}{l}\text { The characteristics of }[\text { Brand } X] \text { is inconsistent with my characteristics }(R) \\
{[\text { Brand } X] \text { does not match who and what I really am }(R)} \\
{[\text { Brand } X] \text { reflects how I see myself }}\end{array}$ & $\begin{array}{l}\text { Wiedmann, } \\
\text { et al. (2009) }\end{array}$ \\
\hline & Uniqueness Value & \\
\hline \multirow[t]{2}{*}{$\begin{array}{l}\text { UV_1 } \\
\text { UV_2 } \\
\text { UV_3 }\end{array}$} & $\begin{array}{l}{[\text { Brand } X] \text { is a brand that is sold everywhere }(R)} \\
{[\text { Brand } X] \text { products give the impression that it is mass-produced }(R)} \\
\text { Few people own }[\text { Brand } X]\end{array}$ & $\begin{array}{l}\text { Wiedmann, } \\
\text { et al. (2009) }\end{array}$ \\
\hline & Patronage Intention & \\
\hline $\begin{array}{l}\text { PI_1 } \\
\text { PI_2 } \\
\text { PI_3 }\end{array}$ & $\begin{array}{l}\text { In my future luxury fashion product purchases, I will buy [Brand X] } \\
\text { It's very likely that I will recommend [Brand X] to a close friend } \\
\text { In the future, I would mainly use [Brand X] for my luxury fashion products }\end{array}$ & $\begin{array}{l}\text { Hieke (2010); } \\
\text { Yoo \& Lee } \\
(2009)\end{array}$ \\
\hline
\end{tabular}

Note: $(\mathrm{R})$ represents reversed scales

All measurement items were translated into Thai language by a professional translator. The translated items were then verified by marketing academic experts for their contextual suitability before being back translated by a different translator. In the case in which the back translation did not agree with the original English version, discussions were made until agreement was reached. All items were measured using a 7-point Likert scale ranging from 'strongly disagree' to 'strongly agree'.

\subsection{2. $P C P$ measurement scale development}

In developing the measurement items for PCP, data from related studies were used. Romani and others (2012) and Wang and Song (2013) suggested that counterfeit market availability 
does have an effect on consumer's attitude towards genuine luxury brand. Commuri (2009) has also reported that genuine luxury brand users feel that counterfeits have increased in number and that their attitude towards the genuine brand is affected when they see counterfeit products being used by other people.

Using the related findings described above, three measurement items were created based on three main ideas: perceived counterfeit market availability, perceived counterfeit adoption, and the potential for counterfeits to increase in number in the future. The measurement items created are listed in Table 3.

TABLE 3: Measurement items created for perceived counterfeit proliferation

\begin{tabular}{|l|l|l|}
\hline $\begin{array}{l}\text { Item } \\
\text { Labels }\end{array}$ & Measurement Items & References \\
\hline PCP_1 & $\begin{array}{l}\text { Counterfeited [Brand } \\
\text { X] is widely available } \\
\text { for purchase }\end{array}$ & $\begin{array}{l}\text { Commuri } \\
(2009) ; \\
\text { Romani et al. } \\
(2012)\end{array}$ \\
\hline PCP_2 & $\begin{array}{l}\text { Counterfeited [Brand } \\
\text { X] is currently widely } \\
\text { adopted by the public }\end{array}$ \\
\hline PCP_3 & $\begin{array}{l}\text { Counterfeited [Brand } \\
\text { X] will probably } \\
\text { increase in number in } \\
\text { the future }\end{array}$ & \\
\hline
\end{tabular}

The measurement items were translated into the Thai language according to the procedures described in section 3.2.1. Scale validation was divided into two phases. In the first phase, the items were initially verified for their relevancy and face validity by in-depth interviews with eight interviewees.

The interviewees were males and females aged 23 to 41 with above average household incomes and were all current customers of luxury fashion brand products at the time. One example of an interviewee was a female, aged 23, who was the daughter of a jewelry shop owner. Another interviewee was a male senior business executive, aged 37, with a salary of more than THB 500,000, or approximately USD 15,000 per month. The respondents felt that Louis Vuitton (LV) was heavily affected by counterfeiting. When asked about the reason why, all the respondents cited the fact that they had witnessed or are aware of counterfeit LV products being worn in public. All of the respondents also reported that they knew where counterfeit LVs were being sold. Five of the respondents also expressed concerns that counterfeit products may increase in number in the near future. This result supports the claim that the measurement items in Table 3 would successfully measure the PCP construct.

After the interview, the measurement items listed in Table 3 were presented to the interviewees, who were then asked whether the items conceptualize luxury brand counterfeit proliferation. All the respondents confirmed that the items captured the concept and that the wording is clear and concise.

In the second phase, PCP measurement items were quantitatively tested with 50 respondents using the principal component exploratory factor analysis. Items were measured using a 7-point Likert scale, ranging from "strongly disagree" to "strongly agree." The results of the analysis demonstrated that all the items loaded significantly onto one construct, proving their suitability as measures of PCP. The construct also showed satisfactory reliability and convergent validity during the initial construct testing.

To control for the differences in brand values inherent in different luxury fashion brands, only one luxury fashion brand was subsequently studied. Using more than one luxury brand would have introduced confounding factors to our study because luxury brand values would be affected not only by PCP but also by the preexisting differences in the different brands. The luxury fashion brand qualifying for our study had to be accepted generally as a luxury brand and also had to be a brand that was experiencing a counterfeiting problem. During the in-depth interviews, respondents revealed that Louis Vuitton (LV) is the most well-known 
luxury brand and is a good representation of a luxury fashion brand that is being counterfeited. Therefore, the brand Louis Vuitton was selected for our study.

\section{RESULTS}

The partial least square structural equation modeling (PLS-SEM) technique was used to analyze the data. The PLS-SEM technique is most appropriate when the main objective of the research is exploratory or when prior theories related to the phenomenon are less developed (Hair, Ringle \& Sarstedt, 2011; Hair, Sarstedt, Hopkins \& Kuppelwieser, 2014). In our case, very few prior studies had quantitatively explored the impact of counterfeit proliferations on luxury brand values. Therefore, since this research adopts the structural equation modeling technique and is directed towards theory building and prediction, the PLS-SEM technique was best suited for the purpose.

The analysis involved two stages. First, the measurement model was assessed, and second, the structural model was assessed. In regard to measurement model assessment, item loadings, construct reliability, internal consistency, and convergent and discriminant validity were tested. After the assessment, it was discovered that QV_6 did not sufficiently load onto the QV construct and was therefore dropped.
After the item refinement, each construct showed Cronbach's a values ranging from 0.716 to 0.877 , indicating that all the constructs had satisfactory levels of construct reliability (Fornell \& Larcker, 1981; Hair, Black, Babin \& Anderson, 2010). The composite reliability value of all the constructs was above 0.7 , confirming that all the constructs had internal consistency (Hair, Ringle \& Sarstedt, 2011). All the constructs also demonstrated satisfying convergent validity, with AVE values above 0.5 (Hair et al., 2010).

All the constructs passed the discriminant validity test by having square root AVE values greater than all the correlations among all other constructs (Hair et al., 2010; Hulland, 1999). Also, as shown in Table 6, all the items significantly $(p<0.01)$ loaded onto their corresponding constructs, with the loading coefficients greater than all the cross-loadings. This confirms the discriminant validity of each construct (Hair et al., 2011). Even though some of the item loadings for QV did not reach 0.7, the resulting Cronbach's a, composite reliability, and AVE values demonstrated that the problem was not severe. The outer loadings, alpha reliability coefficients, AVE values, and composite reliability for all the constructs are provided in Table 4, and the construct correlation matrix is illustrated in Table 5. 
TABLE 4: Assessment of measurement model

\begin{tabular}{|c|c|c|c|c|c|}
\hline & & $\begin{array}{c}\text { Outer } \\
\text { loadings }\end{array}$ & $\begin{array}{l}\text { Cronbach's } \\
\text { alpha }\end{array}$ & AVE & $\begin{array}{l}\text { Composite } \\
\text { reliability }\end{array}$ \\
\hline $\begin{array}{l}\text { Perceived counterfeit } \\
\text { proliferation }(P C P)\end{array}$ & $\begin{array}{l}\text { PCP_1 } \\
\text { PCP_2 } \\
\text { PCP_3 }\end{array}$ & $\begin{array}{l}0.918 \\
0.936 \\
0.751\end{array}$ & 0.848 & 0.771 & 0.904 \\
\hline Quality value (QV) & $\begin{array}{l}\text { QV_1 } \\
\text { QV_2 } \\
\text { QV_3 } \\
\text { QV_4 } \\
\text { QV_5 }\end{array}$ & $\begin{array}{l}0.666 \\
0.685 \\
0.725 \\
0.701 \\
0.802\end{array}$ & 0.771 & 0.515 & 0.841 \\
\hline Hedonic value (HV) & $\begin{array}{l}\mathrm{HV} \text { _1 } \\
\mathrm{HV} \_2 \\
\mathrm{HV} \_3 \\
\mathrm{HV} \_4 \\
\mathrm{HV} \text {-5 }\end{array}$ & $\begin{array}{l}0.867 \\
0.726 \\
0.819 \\
0.793 \\
0.872\end{array}$ & 0.875 & 0.667 & 0.909 \\
\hline $\begin{array}{l}\text { Conspicuous value } \\
\text { (CV) }\end{array}$ & $\begin{array}{l}C V_{-} 1 \\
C V_{-} 2 \\
C V \_3 \\
C V \_4\end{array}$ & $\begin{array}{l}0.736 \\
0.860 \\
0.801 \\
0.731 \\
\end{array}$ & 0.789 & 0.614 & 0.864 \\
\hline $\begin{array}{l}\text { Extended-self value } \\
\text { (EV) }\end{array}$ & $\begin{array}{l}\text { EV_1 } \\
\text { EV_2 } \\
\text { EV_3 }\end{array}$ & $\begin{array}{l}0.853 \\
0.883 \\
0.729 \\
\end{array}$ & 0.760 & 0.680 & 0.863 \\
\hline $\begin{array}{l}\text { Uniqueness value } \\
\text { (UV) }\end{array}$ & $\begin{array}{l}\text { UV_1 } \\
\text { UV_2 } \\
\text { UV_3 }\end{array}$ & $\begin{array}{l}0.798 \\
0.823 \\
0.775 \\
\end{array}$ & 0.716 & 0.638 & 0.841 \\
\hline $\begin{array}{l}\text { Patronage intention } \\
\text { (PI) }\end{array}$ & $\begin{array}{l}\text { PI_1 } \\
\text { PI_2 } \\
\text { PI_3 }\end{array}$ & $\begin{array}{l}0.916 \\
0.878 \\
0.892 \\
\end{array}$ & 0.877 & 0.802 & 0.924 \\
\hline
\end{tabular}

TABLE 5: Construct correlation matrix

\begin{tabular}{|l|c|c|c|c|c|c|c|c|c|}
\hline & Means & SD & PCP & HV & PI & CV & QV & EV & UV \\
\hline PCP & 5.619 & 1.152 & $\mathbf{0 . 8 7 2}$ & & & & & & \\
\hline HV & 3.696 & 1.244 & -0.011 & $\mathbf{0 . 8 1 7}$ & & & & & \\
\hline PI & 3.190 & 1.350 & 0.030 & 0.786 & $\mathbf{0 . 8 9 6}$ & & & & \\
\hline CV & 4.230 & 1.151 & -0.105 & 0.557 & 0.497 & $\mathbf{0 . 7 8 4}$ & & & \\
\hline QV & 5.278 & 0.795 & 0.104 & 0.297 & 0.351 & 0.274 & $\mathbf{0 . 7 1 7}$ & & \\
\hline EV & 3.027 & 1.236 & -0.071 & 0.781 & 0.695 & 0.409 & 0.144 & $\mathbf{0 . 8 2 4}$ & \\
\hline UV & 3.260 & 1.196 & -0.254 & -0.144 & -0.083 & 0.004 & 0.074 & -0.105 & $\mathbf{0 . 7 9 9}$ \\
\hline
\end{tabular}

Note: The main diagonal values are square root AVEs 
TABLE 6: Cross-loadings analysis

\begin{tabular}{|c|c|c|c|c|c|c|c|c|}
\hline & & PCP & QV & HV & CV & EV & UV & PI \\
\hline \multirow[t]{3}{*}{ PCP } & PCP_1 & 0.918 & 0.163 & 0.049 & -0.098 & -0.042 & -0.251 & 0.072 \\
\hline & PCP_2 & 0.936 & 0.053 & -0.034 & -0.118 & -0.073 & -0.253 & -0.024 \\
\hline & PCP_3 & 0.751 & 0.023 & -0.086 & -0.036 & -0.088 & -0.120 & 0.032 \\
\hline \multirow[t]{5}{*}{ QV } & QV_1 & 0.041 & 0.666 & 0.201 & 0.290 & 0.108 & 0.118 & 0.192 \\
\hline & QV_2 & 0.056 & 0.685 & 0.148 & 0.171 & 0.039 & 0.150 & 0.167 \\
\hline & QV_3 & 0.114 & 0.725 & 0.165 & 0.142 & 0.074 & -0.016 & 0.214 \\
\hline & QV_4 & 0.115 & 0.701 & 0.228 & 0.149 & 0.079 & 0.068 & 0.255 \\
\hline & QV_5 & 0.048 & 0.802 & 0.282 & 0.240 & 0.175 & 0.006 & 0.361 \\
\hline \multirow[t]{5}{*}{ HV } & HV_1 & 0.001 & 0.266 & 0.867 & 0.455 & 0.672 & -0.187 & 0.677 \\
\hline & HV_2 & -0.055 & 0.207 & 0.726 & 0.518 & 0.494 & -0.178 & 0.520 \\
\hline & HV_3 & -0.044 & 0.221 & 0.819 & 0.517 & 0.626 & -0.100 & 0.589 \\
\hline & HV_4 & -0.011 & 0.203 & 0.793 & 0.357 & 0.634 & -0.082 & 0.580 \\
\hline & HV_5 & 0.041 & 0.299 & 0.872 & 0.450 & 0.733 & -0.060 & 0.795 \\
\hline \multirow[t]{4}{*}{ CV } & CV_1 & -0.066 & 0.338 & 0.358 & 0.736 & 0.217 & 0.110 & 0.348 \\
\hline & CV_2 & -0.080 & 0.169 & 0.450 & 0.860 & 0.341 & -0.063 & 0.395 \\
\hline & CV_3 & -0.075 & 0.277 & 0.433 & 0.801 & 0.304 & 0.003 & 0.388 \\
\hline & CV_4 & -0.104 & 0.096 & 0.488 & 0.731 & 0.400 & -0.024 & 0.419 \\
\hline \multirow[t]{3}{*}{ EV } & EV_1 & -0.053 & 0.127 & 0.606 & 0.252 & 0.853 & -0.047 & 0.531 \\
\hline & EV_2 & -0.073 & 0.153 & 0.683 & 0.293 & 0.883 & -0.080 & 0.605 \\
\hline & EV_3 & -0.047 & 0.073 & 0.633 & 0.460 & 0.729 & -0.130 & 0.574 \\
\hline \multirow[t]{3}{*}{ UV } & UV_1 & -0.194 & 0.018 & -0.125 & -0.070 & -0.105 & 0.798 & -0.093 \\
\hline & UV_2 & -0.183 & 0.096 & -0.183 & -0.013 & -0.128 & 0.823 & -0.113 \\
\hline & UV_3 & -0.229 & 0.063 & -0.038 & 0.091 & -0.020 & 0.775 & 0.004 \\
\hline \multirow[t]{3}{*}{ PI } & Pl_1 & 0.072 & 0.315 & 0.793 & 0.461 & 0.679 & -0.108 & 0.916 \\
\hline & PI_2 & 0.046 & 0.353 & 0.628 & 0.400 & 0.576 & -0.112 & 0.878 \\
\hline & PI_3 & -0.044 & 0.280 & 0.678 & 0.473 & 0.606 & -0.002 & 0.892 \\
\hline
\end{tabular}

In terms of structural model evaluation, the significance of each path coefficient was assessed using the t-values. The critical t-values for signif- icant path coefficients are 1.65 (at a 10-percent level), 1.96 (at a 5-percent level) and 2.58 (at a 1-percent level) (Hair et al., 2011; Wong, 2013). 


\section{FIGURE 2: Resulting path coefficients and corresponding t-values}

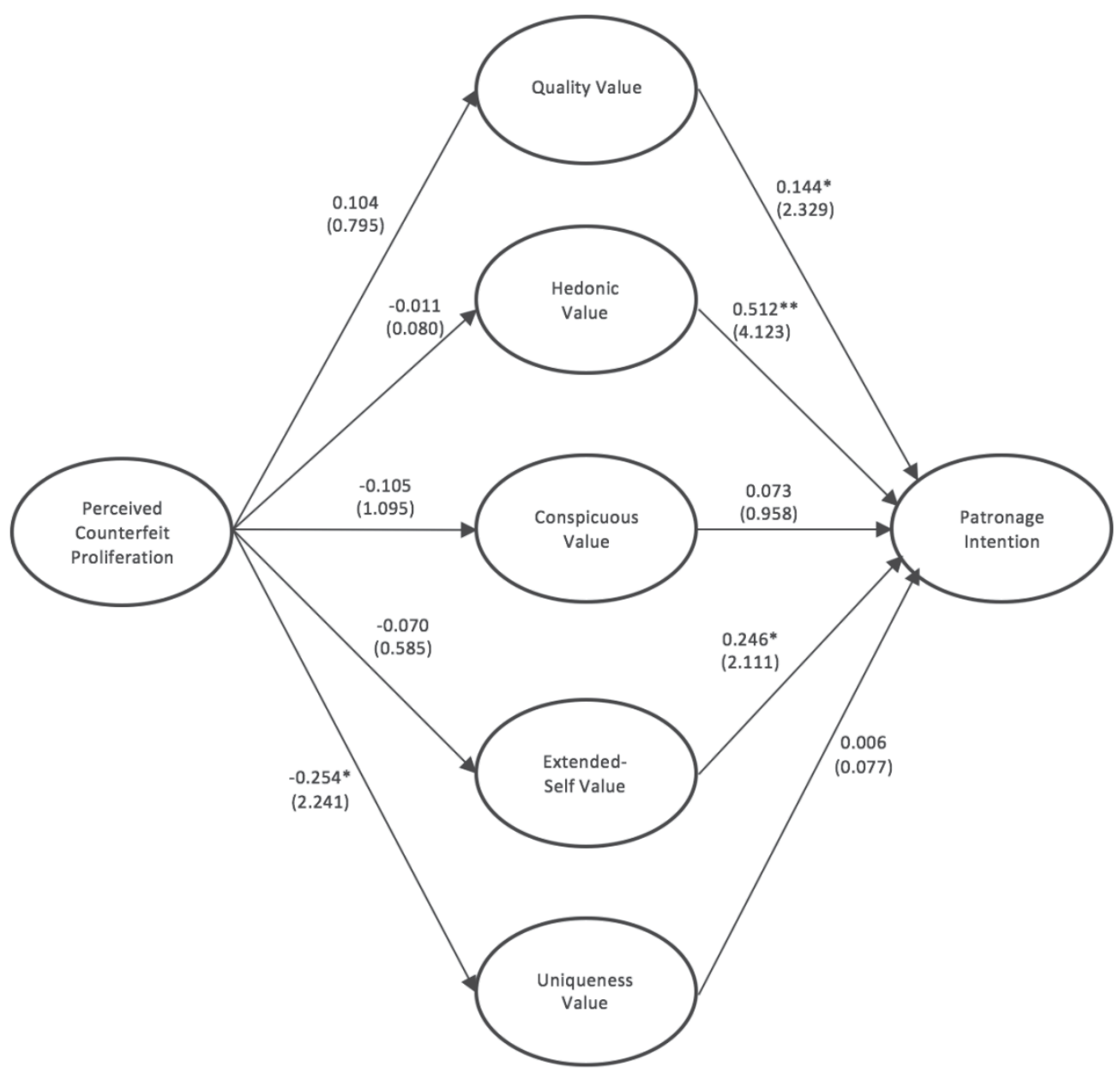

Note: ** indicates 0.01 significance level; * indicates 0.05 significance level; t-values are indicated in brackets

Figure 2 shows the resulting path coefficients and corresponding t-values. With respect to the impacts of the five luxury brand values on patronage intention (PI), QV, HV, and EV all have significant positive impacts on PI with beta coefficients of 0.123 ( $p<0.05), 0.535$ ( $p<0.01)$, and $0.237(p<0.05)$ respectively. Therefore, Hypothesis 1 can be accepted at a 0.05 significance level, Hypothesis 2 can be accepted at a 0.01 significance level, and Hypothesis 4 can be accepted at a 0.05 significance level. However, CV and UV showed no significant impact on PI. This means that Hypotheses 3 and 5 cannot be accepted. Based on the path coefficients, the brand values that are the most important for $\mathrm{PI}$ are HV, EV, QV.

As can be seen from Figure 2, PCP has a significant negative impact on UV with beta coefficient of -0.245 ( $p<0.05$ ). This means that $\mathrm{Hy}$ pothesis 6 can be accepted at a 0.05 significance level. However, PCP was found to have no significant impact on any other luxury brand values (QV, HV, CV, or EV). The means that Hypotheses 7 and 8 cannot be accepted while Hypotheses 9 and 10 cannot be rejected. Numerical results are summarized in Table 7 and findings will be discussed in the next section. 
TABLE 7: Path coefficients of the model

\begin{tabular}{|l|c|c|c|l|}
\hline Path & Beta coefficients & t-values & $\mathbf{R}^{2}$ values & Hypothesis testing \\
\hline $\mathrm{QV} \rightarrow \mathrm{PI}$ & 0.144 & 2.329 & 0.659 & H1: Accepted \\
\hline $\mathrm{HV} \rightarrow \mathrm{PI}$ & 0.512 & 4.123 & & H2: Accepted \\
\hline $\mathrm{CV} \rightarrow \mathrm{PI}$ & 0.073 & 0.958 & & H3: Not accepted \\
\hline $\mathrm{EV} \rightarrow \mathrm{PI}$ & 0.246 & 2.111 & & H4: Accepted \\
\hline $\mathrm{UV} \rightarrow \mathrm{PI}$ & 0.006 & 0.077 & & H5: Not accepted \\
\hline $\mathrm{PCP} \rightarrow \mathrm{UV}$ & -0.254 & 2.241 & 0.064 & H6: Accepted \\
\hline $\mathrm{PCP} \rightarrow \mathrm{EV}$ & -0.070 & 0.585 & 0.005 & H7: Not accepted \\
\hline $\mathrm{PCP} \rightarrow \mathrm{CV}$ & -0.105 & 1.059 & 0.011 & H8: Not accepted \\
\hline $\mathrm{PCP} \rightarrow \mathrm{HV}$ & -0.011 & 0.080 & 0.00 & H9: Not rejected \\
\hline $\mathrm{PCP} \rightarrow \mathrm{QV}$ & 0.104 & 0.795 & 0.011 & H10: Not rejected \\
\hline
\end{tabular}

\section{DISCUSSION AND IMPLICATIONS}

This study contributes to the better theoretical understanding of how perceived counterfeit proliferation affects the five luxury brand values of the original luxury fashion brands for consumers in Southeast Asian region. Insight into how the brand values relate to patronage intention was also gained.

Our findings reveal that the impact of counterfeit proliferation on luxury brand values and patronage intention is a complex phenomenon. Contrary to what was hypothesized, perceived counterfeit proliferation had no significant impact on extended-self and conspicuous values. This indicates that the proliferation of counterfeit luxury fashion brands cannot be viewed in the same way as the proliferation of authentic luxury fashion brands.

Studies by Yang and Mattila (2014) and Yang, Zhang and Mattila (2016) have revealed that certain groups of authentic luxury brand consumers exhibit negative attitudinal change towards their favorite luxury brands when those brands are adopted by less affluent consumers. However, the phenomenon is different for the proliferation of counterfeit luxury fashion brands in a Southeast Asian country such as Thailand. Or results suggest that, apart from uniqueness value, consumers do not feel that counterfeit prolifer- ations affect luxury brand values. Amaral and Loken (2016) have suggested that the negative images of counterfeit users can be transferred to the original brand. Nevertheless, this might not be the case for the consumers studied in this research.

It was discussed earlier that counterfeit luxury brand users generally project an image of being less affluent. Should such an image be transferred to the original brand, counterfeit proliferation would negatively affect conspicuous value and extended-self value. However, our study shows that the negative images of the counterfeit users are not transferred to the original brand, contradicting what Amaral and Loken (2016) have proposed.

The study by Commuri (2009) revealed that consumers in Thailand and India can tell authentic and counterfeit luxury products apart. The consumers' ability to tell the difference between genuine and counterfeit products is possibly the factor that prevents the negative images of the counterfeit users from being transferred to the original brand.

When consumers can tell genuine article and counterfeits apart, the connection between the images of counterfeit users and the original brand is destroyed. Penz and Stöttinger (2008) suggested that consumers' attitudes towards counterfeits are negative, but that the cognitive concepts of counterfeits and original brands 
do not overlap, and attitudes toward counterfeits are not linked back to the original brands. Nia and Zaichkowsky (2000) also reported that counterfeit proliferation has no significant effect on the acceptance of and admiration for the genuine brand. Similarly, Hieke (2010) demonstrated that counterfeits do not affect the luxury perception of the original brand, which includes conspicuous and extended-self values. Even though the similarity between the copy and the original products can cause the uniqueness value of the original brand to be impaired by counterfeit proliferation, the ability of Southeast Asian consumers to discern between genuine and counterfeit products could help prevent the negative associations of counterfeit users from impairing the extended-self and conspicuous values of the original brand.

And contrary to what was hypothesized, uniqueness value and conspicuous value have no significant impact on patronage intention. This is possibly due to the effect of culture. Phau and Prendergast (2000) found that Asian consumers, unlike western consumers, do not value rarity when consuming luxury brands.

Asian countries have been regarded as being collectivistic (Hofstede \& Bond, 1988; Wong \& Ahuvia, 1998). According to Singelis, Triandis, Bhawuk and Gelfand (1995), individualism and collectivism can also be categorized as vertical or horizontal. It is possible that Thai consumers are inherently horizontal collectivists, or individuals who perceive themselves as part of the collective and emphasize equality among all members (Singelis et al., 1995). The fact that consumers do not base their patronage intention on conspicuous value implies that Thai people do not put emphasis on status building. The insignificant relationship between uniqueness value and patronage intention can also mean that Thai consumers do not put much emphasis on being autonomous and that they consider themselves as part of the collective. This is unlike in the vertical individualistic countries, such as the United States (Sivadas, Bruvold \& Nelson, 2008), where people would put more emphasis on conspicuous consumption (Chao \& Schor, 1998; Eastman, Fredenberger, Campbell \& Calvert, 1997).

The present study revealed that consumers in Southeast Asian countries such as Thailand place most emphasis on hedonic value, followed by extended-self and quality value when making decisions on luxury fashion brand patronage. This suggests that Southeast Asian consumers give more importance to personal motives (hedonic and extended-self value) than to interpersonal motives (conspicuous, uniqueness, and quality value) (Vigneron \& Johnson, 2004). It can hence be argued that Southeast Asian consumers such as those in Thailand consume luxury brands as a means of self-fulfillment rather than a means of status portrayal.

In terms of managerial implications, results suggested that brand managers should pay extra attention to the sensory pleasures that customers derive from luxury fashion brands. This also includes enhancing the in-store experience to increase satisfaction. In addition, it is important for brand managers to make sure that their brands convey the images that align with what their target customers wish to portray. Failing to do so might ultimately result in the loss of market share. Quality is another thing brand managers should never forget to pay attention to. Workmanship and performance reliability are what every customer expects from a luxury fashion brand. Therefore, not being able to keep up with the quality standard may serve to damage the brand value.

Lastly, even though counterfeit proliferation has proved to only negatively affect uniqueness value, which does not have any significant relationship with patronage intention, luxury fashion brand managers should not stop making their products distinct from counterfeits. This is so because consumers are currently able to tell genuine products and counterfeits apart. However, once counterfeits have been developed to the extent that it is hard to distinguish between the real and the fake, counterfeit proliferation might begin to have a negative impact on other brand values. 


\section{LIMITATIONS AND FUTURE RESEARCH}

Despite its contributions, this research study does have some limitations. First, it was conducted in Thailand, where the culture is inherently different from that of Western countries. As discussed earlier that culture could possibly affect consumers' emphasis on the different dimensions of brand value when consuming luxury products, and it is highly likely that results would be different if this research was conducted in Western countries. Therefore, since culture is beyond the scope of this study, it is a good idea for future research to explore the moderating effect of culture.

Also, in order to control for the difference in brand values inherent in different luxury fashion brands, this research only focused on the Louis Vuitton (LV) brand. Future research should try to conduct studies on other luxury fashion brands to test the generalizability of the results. It is also possible that LV is overexposed in emerging markets such as Thailand. It would be interesting to test how luxury brand overexposure affects luxury fashion brand values and how it is correlated to the effects of counterfeit proliferation on luxury brand values.

Another interesting direction for future research would be to control for the product category, such as belts and handbags, for each luxury brand. As different products are used on different occasions, it might be advisable to study how results would differ for different product categories.

\section{ACKNOWLEDGEMENTS}

This research was supported by a grant from "The $100^{\text {th }}$ Anniversary Chulalongkorn University Fund for Doctoral Scholarship" and "The 90 th Anniversary Chulalongkorn University Fund" (Ratchadapiseksomphot Endowment Fund).

\section{References}

1. Amaral, N., \& Loken, B. (2016). Viewing Usage of Counterfeit Luxury Goods: Social Identity and Social Hierarchy Effects on Dilution and Enhancement of Genuine Luxury Brands. Journal of Consumer Psychology, 26(4), 483-495.

2. Armstrong, G., \& Kotler, P. (2013). Marketing: An Introduction (1 $1^{\text {th }}$ ed). Harlow: Pearson Education Limited.

3. Belk, R. (1988). Possessions and the Extended Self. Journal of Consumer Research, 15(2), 139-168.

4. Chao, A., \& Schor, J. (1998). Empirical Tests of Status Consumption: Evidence from Women's Cosmetics. Journal of Economic Psychology, 19(1), 107-131.

5. Chattalas, M., \& Shukla, P. (2015). Impact of Value Perceptions on Luxury Purchase Intentions: a Developed Market Comparison. Luxury Research Journal, 1(1), 40-57.

6. Chen, S., \& Lamberti, L. (2015). Entering the Dragon's Nest: Exploring Chinese Upper-Class Consumers' Perception of Luxury. Qualitative Market Research: An International Journal, 18(1), 4-29.

7. Chuchinprakarn, S. (2003). Consumption of Counterfeit Goods in Thailand: Who Are the Patrons? E-European Advances in Consumer Research , 6, 48-53.

8. Commuri, S. (2009). The Impact of Counterfeiting on Genuine-Item Consumers' Brand Relationships. Journal of Marketing, 73(3), 86-98.

9. Corneo, G., \& Jeanne, O. (1997). Conspicuous Consumption, Snobbism and Conformism. Journal of Public Economics, 66, 55-71.

10. Deloitte (2015). Global Powers of Luxury Goods 2015: Engaging the Future Luxury Consumer. Retrieved from Deloitte: https://www2.deloitte.com/sg/en/pages/consumer- business/articles/ global-powers-luxury-goods-2015-pr.html 
11. Dittmar, H. (1994). Material Possessions as Stereotypes: Material Images of Different Socio-Economic Groups. Journal of Economic Psychology, 15(4), 561-585.

12. Dubois, B., Laurent, G., \& Czellar, S. (2001). Consumer Rapport to Luxury: Analyzing Complex and Ambivalent Attitudes. Consumer Research Working Paper No. 736, HEC, Jouy-en-Josas, France.

13. Eastman, J., Fredenberger, B., Campbell, D., \& Calvert, S. (1997). The Relationship Between Status Consumption and Materialism: A Cross-Cultural Comparison of Chinese, Mexican, and American Student. Journal of Marketing Theory and Practice, 5(1), 52-66.

14. Ehrlich, R. (2015). The Secret Lives of Thailand's Counterfeiters. Retrieved from http://edition.cnn. com/2015/06/15/travel/thailand-counterfeiters-fake/

15. Euromonitor (2016). Luxury goods in Thailand. Retrieved from http://www. euromonitor.com/luxury-goods-in-thailand/report

16. Flynn, L., Goldsmith, R., \& Pollitte, W. (2016). Materialism, Status Consumption, and Market Involved Consumers. Psychology \& Marketing, 33(9), 761-776.

17. Fornell, C., \& Larcker, D. (1981). Evaluating Structural Equation Models with Unobservable Variables and Measurement Error. Journal of Marketing Research, 18, 39-50.

18. Fournier, S. (1998). Consumers and Their Brands: Developing Relationship Theory in Consumer Research. Journal of Consumer Research, 24(4), 343-353.

19. Gabrielli, V., Grappi, S., \& Baghi, I. (2012). Does Counterfeiting Affect Luxury Customer-Based Brand Equity?. Journal of Brand Management, 19(7), 567-580.

20. Gentry, J., Putrevu, S., \& Shultz, C. (2006). The Effects of Counterfeiting on Consumer Search. Journal of Consumer Behaviour, 5(3), 245-256.

21. Goldsmith, R., Flynn, L., \& Kim, D. (2010). Status Consumption and Price Sensitivity. Journal of Marketing Theory and Practice, 18(4), 323-338.

22. Hair, J., Black, W., Babin, B., \& Anderson, R. (2010). Multivariate Data Analysis (7th ed.). Upper Saddle River, NJ: Pearson.

23. Hair, J., Ringle, C., \& Sarstedt, M. (2011). PLS-SEM: Indeed a Silver Bullet. Journal of Marketing Theory and Practice, 19(2), 139-151.

24. Hair, J., Sarstedt, M., Hopkins, L., \& Kuppelwieser, V. (2014). Partial Least Squares Structural Equation Modeling (PLS-SEM): An Emerging Tool in Business Research. European Business Review, 26(2), 106-121.

25. Hellofs, L., \& Jacobson, R. (1999). Market Share and Customers' Perceptions of Quality: When can Firms Grow Their Way to Higher Versus Lower Quality?. The Journal of Marketing, 63(1), 16-25.

26. Hieke, S. (2010). Effects of counterfeits on the image of luxury brands: An empirical study from the customer perspective. Journal of Brand Management, 18(2), 159-173.

27. Hilton, B., Choi, C., \& Chen, S. (2004). The Ethics of Counterfeiting in the Fashion Industry: Quality, Credence and Profit Issues. Journal of Business Ethics, 55, 345-354.

28. Hofstede, G., \& Bond, M. (1988). The Confucius Connection: From Cultural Roots To Economic Growth. Organizational dynamics, 16(4), 5-21.

29. Holt, D. (1995). How Consumers Consume: A Typology of Consumption Practices. Journal of Consumer Research, 22(1), 1-16.

30. Hulland, J. (1999). Use of Partial Least Squares (PLS) in Strategic Management Research: A Review of Four Recent Studies. Strategic Management Journal, 20(2), 195-204.

31. Kahle, L. (1995). Observations: Role-Relaxed Consumers: Empirical Evidence. Journal of Advertising Reseach, 35(2), 66-71.

32. Kapferer, J.-N. (1998). Why Are We Seduced by Luxury Brands?. The Journal of Brand Management, 6(1), 44-49.

33. Kasser, T. (2016). Materialistic Values and Goals. Annual Review of Psychology, 67, 489-514. 
34. Keller, K. (2016). Reflections on Customer-Based Brand Equity: Perspectives, Progress, and Priorities. AMS Review, 6(1/2), 1-16.

35. Lassar, W., Mittal, B., \& Sharma, A. (1995). Measuring Customer-Based Brand Equity. Journal of Consumer Marketing, 12(4), 11-19.

36. Lee, M. (2011). The Effect of Counterfeits on the Perceptions toward Luxury Fashion Brands. Journal of the Korean Society of Clothing and Textiles, 35(12), 1466-1476.

37. Lowe, R. (2013). War on Fakes. Retrieved from http://www.ibanet.org/Article/NewDetail.aspx?ArticleUid=02fb8505-e9c4-4f23-b271-c5bf64a8326d

38. Lynn, M. (1991). Scarcity Effects on Value: A Quantitative Review of the Commodity Theory Literature. Psychology \& Marketing, 8(1), 43-57.

39. Moon, J., Chadee, D., \& Tikoo, S. (2008). Culture, Product Type, and Price Influences on Consumer Purchase Intention to Buy Personalized Products Online. Journal of Business Research, 61(1), 31-39.

40. Nia, A., \& Zaichkowsky, J. (2000). Do counterfeits devalue the ownership of luxury brands?. Journal of Product and Brand Management, 9(7), 1061-1081.

41. Penz, E., \& Stöttinger, B. (2008). Original Brands and Counterfeit Brands - Do They Have Anything in Common?. Journal of Consumer Behaviour, 7(2), 146-163.

42. Phau, I., \& Prendergast, G. (2000). Consuming Luxury Brands: The Relevance of the 'Rarity Principle'. Journal of Brand Management, 8(2), 122-138.

43. Romani, S., Gistri, G., \& Pace, S. (2012). When Counterfeits Raise the Appeal of Luxury Brands. Marketing Letters, 23, 807-824.

44. Sheth, J., Newman, B., \& Gross, B. (1991). Why We Buy What We Buy: A Theory of Consumption Values. Journal of Business Research, 22, 159-170.

45. Simmel, G. (1957). Fashion. The American Journal of Sociology, 62(6), 541-558.

46. Singelis, T., Triandis, H., Bhawuk, D., \& Gelfand, M. (1995). Horizontal and Vertical Dimensions of Individualism and Collectivism: A Theoretical and Measurement Refinement. Cross-Cultural Research, 29(3), 240-275.

47. Sirgy, J. (1985). Using Self-Congruity and Ideal Congruity to Predict Purchase Motivation. Journal of Business Research, 13, 195-206.

48. Sirgy, M., Grewal, D., \& Mangleburg, T. (2000). Retail Environment, Self-Congruity, and Retail Patronage: An Integrative Model and a Research Agenda. Journal of Business research, 49(2), 127-138.

49. Sivadas, E., Bruvold, N., \& Nelson, M. (2008). A Reduced Version of the Horizontal and Vertical Individualism and Collectivism Scale: A Four-Country Assessment. Journal of Business Research, 61(3), 201-210.

50. Sun, G., D'Alessandro, S., \& Johnson, L. (2016). Exploring Luxury Value Perceptions in China: Direct and Indirect Effects. International Journal of Market Research, 58(5), 711-731.

51. Sweeney, J., \& Soutar, G. (2001). Consumer Perceived Value: The development of a Multiple Item Scale. Journal of Retailing, 77, 203-220.

52. The Economist. (2015). Counterfeit.com. Retrieved from http://www.economist.com/news/business/21660111-makers-expensive-bags-clothes-and-watches-are-fighting-fakery-courts-battle

53. Tynan, C., McKechnie, S., \& Chhuon, C. (2010). Co-Creating Value for Luxury Brands. Journal of Business Research, 63, 1156-1163.

54. Veblen, T. (1989). The Theory of Leisure Class. Harrisburg, PA: Macmillan.

55. Vigneron, F., \& Johnson, L. (1999). A Review and a Conceptual Framework of Prestige-Seeking Consumer Behavior. Academy of Marketing Science Review, 1, 1-15.

56. Vigneron, F., \& Johnson, L. W. (2004). Measuring Perceptions of Brand Luxury. Journal of Brand Management, 11(6), 484-506. 
57. Wang, Y., \& Song, Y. (2013). Counterfeiting: Friend or Foe of Luxury Brands? An Examination of Chinese Consumers' Attitudes Toward Counterfeit Luxury Brands. Journal of Global Marketing, 26(4), 173-187.

58. Wiedmann, K-P., Hennigs, N., \& Siebels, A. (2009). Value-Based Segmentation of Luxury Consumption Behavior. Psychology \& Marketing, 26(7), 625-651.

59. Wong, K-K. (2013). Partial Least Squares Structural Equation Modeking (PLS-SEM) Techniques Using SmartPLS. Marketing Bulletin, 24(2), 1-32.

60. Wong, N., \& Ahuvia, A. (1998). Personal Taste and Family Face: Luxury Consumption in Confucian and Western Societies. Psychology \& Marketing, 15(5), 423-441.

61. Yang, W., \& Mattila, A. (2014). Do affluent customers care when luxury brands go mass?: The role of product type and. International Journal of Contemporary Hospitality Management, 26(4), 526543.

62. Yang, W., Zhang, L., \& Mattila, A. (2016). Luxe for Less: How Do Consumers React to Luxury Hotel Price Promotions? The Moderating Role of Consumers' Need for Status. Cornell Hospitality Quarterly, 57(1), 82-92.

63. Yoo, B., \& Lee, S.-H. (2009). Buy Genuine Luxury Fashion Products Or Counterfeits? NA-Advances in Consumer Research, 36, 280-286. 